\title{
Clinical Outcome of Single Antibiotic versus Combination Antibiotics in Enteric Fever
}

\author{
Tazin Afrose Shah $^{1 *}$, Farhan Matin ${ }^{2}$, Anarul Islam ${ }^{3}$, Md. Mahbubur Rahman ${ }^{4}$, Mohiduzzaman Tony ${ }^{5}$, SM
} Rokonuzzaman ${ }^{6}$, Md. Hyder Ali $^{7}$

\footnotetext{
${ }^{1}$ Associate Professor, Department of Medicine, Uttara Adhunik Medical College (UAMC), Dhaka, Bangladesh

${ }^{2}$ Associate Professor, Department of Radiology and Imaging, Uttara Adhunik Medical College (UAMC), Dhaka, Bangladesh

${ }^{3}$ Assistant Professor, Department of Respiratory Medicine, Uttara Adhunik Medical College (UAMC), Dhaka, Bangladesh

${ }^{4}$ Associate Professor, Department of Gastroenterology, Uttara Adhunik Medical College (UAMC), Dhaka, Bangladesh

${ }^{5}$ Associate Professor, Department of Surgery, Uttara Adhunik Medical College (UAMC), Dhaka, Bangladesh

${ }^{6}$ Professor \& Head, Department of Medicine, Uttara Adhunik Medical College (UAMC), Dhaka, Bangladesh

${ }^{7}$ Professor, Department of Medicine, Uttara Adhunik Medical College (UAMC), Dhaka, Bangladesh
}

| Received: 15.12.2020 | Accepted: 26.12.2020 | Published: 30.12.2020

*Corresponding author: Dr. Tazin Afrose Shah

\section{Abstract}

\section{Original Research Article}

Background: In recent times the treatment of enteric fever is becoming more and more difficult. The aim of our study was to find out a cost effective way of treatment of enteric fever and to determine the success rate \& fever clearance time of ceftriaxone as monotherapy in comparison to combinations of cefixime plus azithromycin. Method: Randomized single blind controlled comparative experimental study carried out in the Department of Medicine, Uttara Adhunik Medical College \& Hospital, and Dhaka, Bangladesh during the period from $1^{\text {st }}$ September, 2015 to $1^{\text {st }}$ September, 2015. A total 96 cases of enteric fever patients were included based on inclusion and exclusion criteria. After taking informed written consent data was collected by a questionnaire and relevant investigations were done. Control group were given inj ceftriaxone and experimental group were given cefixime plus azithromycin. Then collected data was analyzed. Main Outcome measures: Age, Sex, response of treatment of Fever, Myalgia, Headache, Anorexia, Constipation, Diarrhoea, Abdominal pain, Cough, Relative bradycardia, Rose spot on trunk, Splenomegaly, Hepatomegaly, Coated tongue and treatment failure. Results: Out of 96 cases majority of cases were seen in the age group of 18-25 years $(30.20 \%)$ followed by $26-33$ years (23.95\%). There was a slight male preponderance with $53.1 \%$ male and $46.9 \%$ female. Majority $(47.92 \%)$ of cases were brought to hospital during the $1^{\text {st }}$ week of illness. Fever was common to all (100\%) cases, followed by headache $(62.5 \%)$, anorexia, and nausea $(62.5 \%)$, abdominal pain $(58.33 \%)$, diarrhoea $(52.08 \%)$, and constipation $(29.16 \%)$ and vomiting $(8.33 \%)$. Less common symptoms were cough $(14.58 \%)$, generalized weakness $(8.33 \%)$, jaundice $(4.16 \%)$, and bloody diarrhoea $(2.08 \%)$. None of the patients had G.I bleeding or rash. Coated tongue was present in $83.33 \%$ patient. Hepatomegaly was present in $66.66 \%$ patients and more common than splenomegaly (41.66\%).Only $41.66 \%$ patients were of toxic looking. Abdominal tenderness was present in $25 \%$ patients, while abdominal distention in $18.75 \%$. Caecal gurgling and relative bradycardia in $10.41 \%$ each. Mean period of defervescence

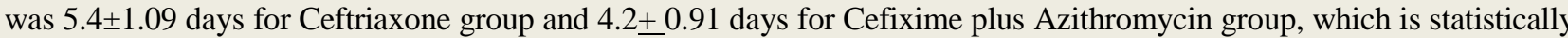
significant. $(\mathrm{p}=.04)$. Duration of therapy was $9.92 \pm 4$ days in group A and $7 \pm 0.00$ days in group $\mathrm{B}$, this is statistically significant. ( $p<0.001)$. Out of 48 cases in group A, 44 patients become afebrile with ceftriaxone treatment, success rate is $91.67 \%$.Out of 48 cases of group B, 2 patients failed to respond and success rate is $95.83 \%$,but this is not statistically significant $(p=0.399)$. Conclusion: The treatment of enteric fever with a combination of antibiotics like Cefixime plus Azithromycin is not inferior to single antibiotic like Ceftriaxone but oral combinations of antibiotic provide a less costly and equally safe and effective oral form of treatment alternative to ceftriaxone. Findings of this were also in accordance with the previous studies with enteric fever. As a small number of patients were studied so findings of this study should be cautiously extrapolated into the broader context.

Key words: Enteric Fever, Antibiotic, Ceftriaxone, Cefixime, Azithromycin.

Copyright $\odot 2020$ The Author(s): This is an open-access article distributed under the terms of the Creative Commons Attribution 4.0 International License (CC BY-NC 4.0) which permits unrestricted use, distribution, and reproduction in any medium for non-commercial use provided the original author and source are credited.

\section{INTRODUCTION}

Despite advances in technology and public health strategies enteric fever remains a major cause of morbidity \& mortality in the developing world. Salmonella Typhi continues to be endemic in developing countries. Worldwide, 22 million infections occur with this organism annually, resulting in 200000 
deaths [1]. Indian subcontinent, which has the highest incidence of the disease, is also an epicenter of enteric fever caused by multidrug-resistant (MDR; resistant to chloramphenicol, ampicillin, and trimethoprimsulfamethoxazole) and nalidixic acid-resistant (NAR) strains, i.e., strains with decreased susceptibility to ciprofloxacin [2-4].

A total of $57 \%$ of S. Typhi strains isolated at a referral center in Dhaka, Bangladesh, in 2005 were MDR and NAR[5].The emergence of multidrugresistant (MDR) S. Typhi led to the introduction of fluoroquinolones as the first-line drug during the last two decades of the 20th century[6]. However, frequent treatment failures of ciprofloxacin against $\mathrm{S}$. Typhi have resulted in the use of third-generation cephalosporins for fluoroquinolones-resistant Salmonella infections. Coincidently, ceftriaxoneresistant S. Typhi has already been reported from Asia [7].

Some patients with enteric fever can show a delayed response or treatment failure with ciprofloxacin both clinically and bacteriologically [8]. The optimum treatment for MDR and NAR enteric fever has not yet been established. A third-generation cephalosporin or high doses of fluoroquinolones (e.g., ciprofloxacin, 20 $\mathrm{mg} / \mathrm{kg} /$ day or levofloxacin, $10 \mathrm{mg} / \mathrm{kg} /$ day) for $10-14$ days are the drugs of choice [2, 3]. Azithromycin $(20 \mathrm{mg} / \mathrm{kg} /$ day) is also a promising agent [9]. However, for any of the regimens, the mean fever clearance times are relatively long $(\approx 7$ days $)$, and the relapse rates are high [2]. So a combination of these regimens can be considered [10]. Towards the end of the last decade, it was observed that fever took longer time than before to clear, and at times failed to respond to ciprofloxacin therapy $[11,13]$ resulting in significant reduction of workload. However it is not clear whether fluoroquinolones can still be used as first-line drug for the treatment of enteric fever. Ceftriaxone, a third generation cephalosporin has become the treatment of choice for typhoid fever in many parts of the world. But the recent report of an isolate of Salmonella Typhi from Bangladesh with a high level of resistance to ceftriaxone means that untreatable enteric fever is a real problem [14]. Because of its high cost, parenteral administration, and requiring hospitalization, ceftriaxone is less than an ideal treatment option in a low resource country like Bangladesh. The availability of the Macrolide class of antibiotics has provided another potential option for the treatment of enteric fever [15]. Rapid movement of azithromycin from blood into tissues results in significant higher concentration in tissue than in plasma. Serum concentration of azithromycin declines in a polyphasic pattern, resulting in an average half-life of 68 hours [16] the prolonged concentration of azithromycin in cells may explain the good results obtained with azithromycin in patients with enteric fever in chile [17] and Egypt [18]. Cefixime, an orally administered third generation cephalosporin, is a commonly used drug in South Asia for the treatment of enteric fever. Although cefixime is recommended as a drug of choice by the World Health Organization (WHO) for the treatment of resistant typhoid fever [19] it has to be administered for a longer duration than the currently used fluoroquinolones. Cefixime is widely trusted to be effective for enteric fever as first line treatment, and is also used as second line therapy when initial treatment with a fluoroquinolone in a patient suspected to be enteric fever fails [20]. The fact that we saw a high overall failure rate associated with cefixime despite all of the strains being fully sensitive in vitro to the drug shows that the mechanism of action of cefixime [21, 22], may not be suited to the eradication of S. Typhi or Paratyphi A from the body or blood, and the poor intracellular penetration into macrophages and reticuloendothelial tissues where the typhoid organisms colonize [23] may be the cause of high failure rates. Clearly there is an urgent need for a treatment [24] that combines ease of oral administration, with speed of clinical response, reduction in secondary transmission and inexpensiveness. So the encouraging results of azithromycin and trusted oral third generation cephalosporin, cefixime combination may help us to choose more safe, cheap and effective alternative to other available drugs. In this scenario, the present study is undertaken to compare the efficacy of ceftriaxone Vs cefixime plus azithromycin in enteric fever to reduce the cost of treatment to approximately $80 \%$, need for hospitalization, reduce the bed occupancy rate and hazards of intravenous administration.

In recent times the treatment of enteric fever is becoming more and more difficult. In spite of use of different antibiotics delayed clinical response is a common scenario. So further research work especially in Bangladesh may be helpful considering the demographics, widespread irrational use of antibiotics and prevailing antibiotic resistance pattern.

\section{METHOD}

It was randomized single blind controlled comparative experimental study carried out in the Department of Medicine, Uttara Adhunik Medical College, and Dhaka, Bangladesh during the period from September, 2015 to August, 2016. Ninety six patients with enteric fever purposively selected for the study. All culture proven cases of Enteric fever. Patients who cannot complete this research work, pregnant ladies, lactating mother and children $<18$ years and patients being treated with antibiotics other than the regimens under present study was excluded for the study sample. After registration of the patient, detail history was taken and physical examination was done. Samples of blood were collected for complete blood count, comment on peripheral blood film with malarial parasite, blood culture \& sensitivity and Widal test. Completion of treatment with clinical cure enrolled patients were discharged All subjects in both the group were asked to 
return immediately if fever develops within four weeks after completion of treatment, to find out the relapse. After completion of collection of data in a pre designed \& structured questionnaire by interviewing and observing every case, tables were prepared by the observed values, mean and standard deviation were calculated. Levels of significance were tested by independent $\mathrm{t}$-test and chi-square $\left(\mathrm{x}^{2}\right)$ test. A P value of $\leq 0.05$ indicated a significant difference between the two groups.

\section{RESULTS}

Table-1: Presenting features of enteric fever $(n=96)$

\begin{tabular}{|l|l|l|}
\hline Complaints & Number of patients & Percentage $(\%)$ \\
\hline Duration: & & \\
$<7$ days & 46 & 47.92 \\
8-14 days & 22 & 22.92 \\
$>14$ days & 28 & 29.16 \\
\hline Abdominal pain & 56 & 58.33 \\
\hline headache & 60 & 62.5 \\
\hline Diarrhoea & 50 & 52.08 \\
\hline Constipation & 28 & 29.16 \\
\hline Jaundice & 4 & 4.16 \\
\hline Vomiting & 8 & 8.33 \\
\hline Anorexia \& nausea & 60 & 62.5 \\
\hline Cough & 14 & 14.58 \\
\hline Weakness & 8 & 8.33 \\
\hline Bloody Diarrhoea & 2 & 2.08 \\
\hline
\end{tabular}

Majority (47.92\%) of cases were brought to hospital during the $1^{\text {st }}$ week of illness followed by $29.16 \%$ patients in the $3^{\text {rd }}$ week or later. Only $22.92 \%$ patients were brought in the $2^{\text {nd }}$ week of illness. Fever was common to all (100\%), followed by headache $(62.5 \%)$, anorexia, and nausea $(62.5 \%)$, abdominal pain
(58.33\%), diarrhoea (52.08\%), constipation (29.16\%) and vomiting $(8.33 \%)$. Less commonly cough $(14.58 \%)$ weakness $(8.33 \%)$, jaundice $(4.16 \%)$, and bloody diarrhoea $(2.08 \%)$ were also noted. None of the patients had G.I bleeding or rash.

Table-2: Physical findings of patients. $(n=96)$

\begin{tabular}{|l|l|l|}
\hline Physical examination & No of patients & \% of patients \\
\hline Coated tongue & 80 & 83.33 \\
\hline Hepatomegaly & 64 & 66.66 \\
\hline Splenomegaly & 40 & 41.66 \\
\hline Toxic look & 40 & 41.66 \\
\hline Dehydration & 10 & 10.41 \\
\hline Abdominal tenderness & 24 & 25.0 \\
\hline Abdominal distension & 18 & 18.75 \\
\hline Jaundice & 4 & 4.16 \\
\hline Mouth ulcer & 2 & 2.08 \\
\hline Caecal gurgling & 10 & 10.41 \\
\hline Relative bradycardia & 10 & 10.41 \\
\hline
\end{tabular}

Coated tongue was present in $83.33 \%$ patient. Hepatomegaly was present in $66.66 \%$ of patients and more common than splenomegaly (41.66\%). Only $41.66 \%$ patients were toxic looking. Abdominal tenderness was present in $25 \%$ patients, while abdominal distension in $18.75 \%$. Jaundice was noted in $4.16 \%$ of patient, while caecal gurgling and relative bradycardia in $10.41 \%$ each. 
Table-3: Comparisons of demographic, clinical and pre-treatment laboratory findings (n=96)

\begin{tabular}{|l|l|l|l|}
\hline Variable & $\begin{array}{l}\text { Group } \\
\text { (Ceftriaxone) } \\
\text { n=48 }\end{array}$ & $\begin{array}{l}\text { Group B (Cefixime } \\
\text { plus Azithromycin) } \\
\text { n=48 }\end{array}$ & p-value \\
\hline $\begin{array}{l}\text { Age(years) } \\
\begin{array}{l}\text { Mean } \\
\text { range }\end{array}\end{array}$ & $\begin{array}{l}26.2 \pm 6.14 \\
(18-53)\end{array}$ & $\begin{array}{l}28.5 \pm 7.22 \\
(18-60)\end{array}$ & 0.110 \\
\hline $\begin{array}{l}\text { Sex } \\
\text { Male }\end{array}$ & $\begin{array}{l}29(60.4 \%) \\
\text { Female }\end{array}$ & $\begin{array}{l}22(45.8 \%) \\
26(54.2 \%\end{array}$ & 0.152 \\
\hline $\begin{array}{l}\text { Weight (kg) } \\
\text { Mean } \pm \text { SD } \\
\text { range }\end{array}$ & $\begin{array}{l}52.2 \pm 6.1 \\
(40-74)\end{array}$ & $\begin{array}{l}53.1 \pm 7.2 \\
(35-75)\end{array}$ & 0.510 \\
\hline $\begin{array}{l}\text { Duration of fever from } \\
\text { of enrollment } \\
\text { Mean } \pm \text { SD }\end{array}$ & & & \\
\hline White blood cell/cmm & $11.25 \pm 2.13$ & $10.52 \pm 2.81$ & 0.155 \\
\hline S.creatinine,mg/dl & $6200 \pm 1236$ & $6600 \pm 1125$ & 0.101 \\
\hline AST, IU/ml & $1.24 \pm .0 .31$ & $1.22 \pm 0.27$ & 0.737 \\
\hline ALT, IU/ml & $40.41 \pm 7.13$ & $37.89 \pm 6.93$ & 0.082 \\
\hline ALP, IU/ml & $41.26 \pm 3.92$ & $39.82 \pm 3.77$ & 0.071 \\
\hline & $91.6 \pm 10.13$ & $94.6 \pm 9.41$ & 0.136 \\
\hline
\end{tabular}

Demographic, clinical and pretreatment there was no significant difference between the laboratory evaluation of the subjects demonstrated that treatment groups.

Table-4: Post treatment clinical parameter $(n=48)$

\begin{tabular}{|l|c|c|c|}
\hline Parameter & Group-A & Group-B & P-value \\
\hline $\begin{array}{l}\text { Defervescence from starting treatment, } \\
\text { Mean days } \pm \text { SD }\end{array}$ & $5.4 \pm 1.09$ & $4.2 \pm 0.91$ & $<0.001$ \\
\hline $\begin{array}{l}\text { Duration of therapy } \\
\text { Mean days } \pm \text { SD }\end{array}$ & $9.92 \pm 4.0$ & $7.00 \pm 1.12$ & $<0.001$ \\
\hline
\end{tabular}

Mean period of defervescence was $5.4 \pm 1.09$ days for ceftriaxone group and $4.2+0.91$ days for cefixime plus azithromycin group, which is statistically significant. ( $\mathrm{p}<0.001)$. Duration of therapy was $9.92 \pm 4$ days in group $\mathrm{A}$ and $7 \pm 1.12$ days in group $\mathrm{B}$, this is statistically significant. $(\mathrm{p}<0.001)$.

Table-5: Treatment outcome $(n=48)$

\begin{tabular}{|c|c|c|c|}
\hline \multirow[t]{2}{*}{ Groups } & \multicolumn{2}{|c|}{ Status of treatment } & \multirow[t]{2}{*}{ P value } \\
\hline & Success & Failure & \\
\hline Group-A (Ceftriaxone) $(\mathrm{n}=48)$ & $44(91.67 \%)$ & $4(8.33 \%)$ & \\
\hline $\begin{array}{lll}\text { Group-B } & \text { (Cefixime plus } \\
\text { Azithromycin })(n=48) & \\
\end{array}$ & $46(95.83 \%)$ & $2(4.17 \%)$ & 0.399 \\
\hline
\end{tabular}

Out of 48 cases in group A, 44 patients become afebrile with ceftriaxone treatment; success rate is $(91.67 \%)$. Out of 48 cases of group B, 2 patients in cefixime plus azithromycin group failed to respond and success rate is $(95.83 \%)$, which is not statistically significant $(\mathrm{p}=0.399)$.

Table-6: Comparison of treatment cost of an index case of $50 \mathrm{~kg}$ body weight $(\mathrm{n}=48)$

\begin{tabular}{|l|l|l|l|}
\hline & Daily required Dose & $\begin{array}{l}\text { Treatment } \\
\text { required }\end{array}$ & $\begin{array}{l}\text { Ratio } \\
\text { of cost }\end{array}$ \\
\hline $\begin{array}{l}\text { Group-A } \\
\text { (Ceftriaxone) }\end{array}$ & $\begin{array}{l}\text { 2 gram 12 hourly (approx. Cost TK } \\
700 / \text { day) }\end{array}$ & $\begin{array}{l}10 \text { days } \\
\text { (approx. Cost } \\
\text { TK 7000) }\end{array}$ & 9.1: 1 \\
\hline $\begin{array}{l}\text { Group-B (Cefixime } \\
\text { plus Azithromycin) }\end{array}$ & $\begin{array}{l}\text { 200mg 12 hourly plus 500mg 12 } \\
\text { hourly( approx Cost TK 110) }\end{array}$ & $\begin{array}{l}\text { 7ays } \\
\text { (approx Cost } \\
\text { TK 770) }\end{array}$ & \\
\hline
\end{tabular}

Ratio of cost of treatment between ceftriaxone and cefixime plus azithromycin is 9.1: 1, which means that $89 \%$ cost reduction is possible in case of treatment of enteric fever with cefixime plus azithromycin. 
Table-7: Adverse effects of drugs $(n=48)$

\begin{tabular}{|l|l|l|l|}
\hline Parameter & $\begin{array}{l}\text { Group-A } \\
\text { Ceftriaxone } \\
(\mathbf{n = 4 8 )} \\
\text { No. }(\%)\end{array}$ & $\begin{array}{l}\text { Group-B } \\
\text { Cefixime plus Azithromycin } \\
(\mathbf{n = 4 8 )} \\
\text { No. }(\boldsymbol{\%})\end{array}$ & p-value \\
\hline Nausea & $4(8.33)$ & $5(10.41)$ & 0.726 \\
\hline Vomiting & $4(8.33)$ & $5(10.41)$ & 0.726 \\
\hline Abdominal discomfort & $0(0.0)$ & $2(4.16)$ & 0.153 \\
\hline
\end{tabular}

Gastrointestinal symptoms, notably nausea, vomiting and abdominal discomfort was the most common adverse effect reported, and more commonly in those treated with cefixime plus azithromycin group than those with ceftriaxone .But this is not statistically significant $(\mathrm{P}>0.05)$.

\section{DISCUSSION}

In this study the clinical outcome of single antibiotic versus combination of antibiotics in enteric fever was studied. Here single agent was ceftriaxone and combination of antibiotics was cefixime plus azithromycin. The study was performed with a view to find a less costly, and equally safe and effective oral form of treatment alternative to ceftriaxone.

Enteric fever may occur at any age. In this study, highest prevalence was found between 18-25 years of age $(30.20 \%)$ followed by $26-33$ years of age $(23.95 \%)$. There is no significant difference in proportion of sexes in most studies. Our study showed slight male preponderance.

Majority (47.92\%) of cases were brought to hospital during the $1^{\text {st }}$ week of illness followed by $29.16 \%$ patients in the $3^{\text {rd }}$ week or later. Only $22.92 \%$ patients were brought in the $2^{\text {nd }}$ week of illness. Fever was common to all (100\%) cases, followed by headache $(62.5 \%)$, anorexia, and nausea $(62.5 \%)$, abdominal pain $(58.33 \%)$, diarrhoea $(52.08 \%)$, and constipation $(29.16 \%)$ and vomiting $(8.33 \%)$. Less common symptoms were cough $(14.58 \%)$ weakness $(8.33 \%)$, jaundice $(4.16 \%)$, and bloody diarrhoea $(2.08 \%)$. None of the patients had G.I bleeding or rash.

Coated tongue was present in $83.33 \%$ patient. Hepatomegaly was present in $66.66 \%$ patients and more common than splenomegaly $(41.66 \%)$. Only $41.66 \%$ patients were toxic looking. Abdominal tenderness was present in $25 \%$ patients, while abdominal distension in $18.75 \%$. Jaundice was noted in $4.16 \%$ of patient, while caecal gurgling and relative bradycardia in $10.41 \%$ each.

In the present study, the patients with enteric fever, admitted in the department of medicine fulfilling the inclusion criteria were randomized to receive inj ceftriaxone $75 \mathrm{mg} / \mathrm{kg} /$ day for 10 days or until three days from defervescence, which one is shorter, as optimal therapy for enteric fever with ceftriaxone is 7-14 days
$[25,26]$ or cefixime plus azithromycin for 7 days $[17$, $18,27]$.

Demographic, clinical and pre-treatment laboratory evaluation of the subjects demonstrates that both the treatment groups were comparable.

Mean period of defervescence was $5.4 \pm 1.09$ days for ceftriaxone group and 4.2 \pm 0.91 days for cefixime plus azithromycin group, which is statistically significant. $(p<0.001)$. Increase in the duration of mean defervescence period in our study probably due to indiscriminate use of antibiotics by unregistered practitioners causing reduced susceptibility of the organisms. Another study conducted in our country, with azithromycin showed a mean defervescence period of $3.82 \pm 1.49$ days [20].

Duration of therapy was $9.92 \pm 4$ days in group A and $7 \pm 1.12$ days in group $B$, this is statistically significant. $(p<0.001)$. Four patients in ceftriaxone group, and two patients in cefixime plus azithromycin group did not respond, they remained febrile by the day 7 and was labeled as failure. These cases were sensitive to ceftriaxone, cefixime and azithromycin but failure was probably due to delayed response. After another 5 days of observation in the hospital with ongoing treatment they became afebrile.

Percentage of success in ceftriaxone group was $91.67 \%$, while $95.83 \%$ in cefixime plus azithromycin group but this is not statistically significant. $(\mathrm{p}=0.399)$.

No subject had a serious adverse event. Gastrointestinal symptoms were commonly reported by both groups, which includes nausea, vomiting and abdominal discomfort, which occurred most frequently in subjects treated with cefixime plus azithromycin group may be due to azithromycin.

However the symptoms were mild and transient, resolving in most cases within one day of initiation of treatment. In no case the symptom was severe enough to require halting the treatment or alteration of antibiotic therapy. Ratio of cost of treatment between ceftriaxone and cefixime plus azithromycin is 9.1:1, which means that $89 \%$ cost reduction is possible in case of treatment of enteric fever with cefixime plus azithromycin. 


\section{LIMITATIONS}

There were some limitations like unavailability of the most of the medical facilities, lack of adequate medical sources and relatively short duration of study period and small study sample. Furthermore this study could have underestimated nonprescription use of antibiotics in the community, because the study was hospital based.

\section{Conclusions and Recommendations}

The irrational use of antibiotics is responsible for delayed response of enteric fever with common treatment options. So newer treatment options are needed. The treatment of enteric fever with a combination of antibiotics like Cefixime plus Azithromycin is not inferior to single antibiotic like Ceftriaxone but oral combinations of antibiotic provide a less costly and equally safe and effective oral form of treatment alternative to ceftriaxone. Findings of this were also in accordance with the previous studies with enteric fever. As a small number of patients were studied so findings of this study should be cautiously extrapolated into the broader context .Further research work could be recommended to evaluate the impact of combination of antibiotics in the treatment of enteric fever. Seminar and workshops could be arranged in the cities, Upazilla and unions to stop indiscriminate use of antibiotics. Mass media can help to build public awareness to decrease indiscriminate use of antibiotics.

\section{REFERENCES}

1. Crump JA, Luby SP, Mintz ED. The global burden of typhoid fever. Bulletin of the World Health Organization. 2004; 82:346-53.

2. Parry CM, Hien TT, Dougan G, White NJ, Farrar JJ. Typhoid fever. N Engl J Med. 2002;347:177082.

3. Bhan MK, Bahl R, Bhatnagar S. Typhoid and paratyphoid fever. Lancet. 2005; 366:749-62.

4. Crump JA, Barrett TJ, Nelson JT, Angulo FJ.Reevaluating fluoroquinolone breakpoints for Salmonella enterica serotypeTyphi and for nonTyphi salmonellae. Clin Infect Dis. 2003; 37:7581.

5. Ahmed D, D'Costa LT, Alam K, Nair GB, Hossain MA. Multidrug-resistant Salmonella enterica serover Typhi isolates with high-level resistance to ciprofloxacin in Dhaka, Bangladesh. Antimicrob Agents Chemother. 2006; 50:3516

6. Ackers ML, Puhr ND, Tauxe RV, Mintz ED. Laboratory-based surveillance of Salmonella serotype Typhi infections in the United States: antimicrobial resistance on the rise. JAMA. 2000; 283:2668-73.

7. Saha SK, Talukder SY, Islam M, Saha S. A highly ceftriaxone-resistant Salmonella Typhi in Bangladesh. Pediatr Infect Dis J. 1999; 18:387.
8. Dutta P, Mitra U, Dutta S, De A, Chatterjee MK, Bhattacharya SK. Ceftriaxone therapy in ciprofloxacin treatment failure typhoid fever in children. Indian J Med Res. 2001; 113:210-3.

9. Parry CM, Ho VN, Phuong LT, Be Bay PV, Lanh MN, Tung LT. Randomized controlled comparison of ofloxacin, azithromycin, and an ofloxacinazithromycin combination for treatment of multidrug-resitant and nalidixic acid-resistant typhoid fever. Antimicrob Agents Chemother. 2007; 51:819-25.

10. Basnyat B, Maskey AP, Zimmerman MD, Murdoch DR. Enteric (typhoid) fever in travelers. Clin Infect Dis. 2005; 41:1467-72

11. Bhat KG, Suresh K: Ciprofloxacin-resistant Salmonella typhi.Natl Med J India. 1999, 12:88.

12. Threlfall EJ, Ward LR, Skinner JA, Smith HR, Lacey S: Ciprofloxacin resistant Salmonella typhi and treatment failure. Lancet. 1999, 353:15901591.

13. Dutta P, Mitra U, Dutta S, De A, Chatterjee MK, Bhattacharya SK: Ceftriaxone therapy in ciprofloxacin treatment failure typhoid fever in children. Indian J Med Res. 2001, 113:210-213.

14. Saha SK, Talukder SY, Islam M, Saha S. A highly ceftriaxone-resistant Salmonella typhi in Bangladesh. The Pediatric infectious disease journal. 1999 Apr 1;18(4):387.

15. Frenck Jr RW, Nakhla I, Sultan Y, Bassily SB, Girgis YF, David J, Butler TC, Girgis NI, Morsy M. Azithromycin versus ceftriaxone for the treatment of uncomplicated typhoid fever in children. Clinical infectious diseases. 2000 Nov 15;31(5):1134-8.

16. Foulds G, Shepard RM, Johnson RB. The pharmacokinetics of azithromycin in human serum and tissues. Journal of Antimicrobial Chemotherapy. 1990 Jan 1;25(suppl_A):73-82.

17. Butler T, Girard AE. Comparative efficacies of azithromycin and ciprofloxacin against experimental salmonella typhimurium infection in mice Antimicrob Chemother. 1993: 31: 313-19.

18. Butler T, Palmino C, Johnson RB, Hopkins SJ. Efficacy of Azithromycin for the treatment of typhoid fever. In programme and Abstracts of the thirty second Inter science conference on antimicrobial agents and chemotherapy, Anaheim, CA,1992, Abstract 1579, American society for microbiology, Washington.

19. Communicable Disease and Surveillance and Response Vaccines and Biological: World Health Organization. Treatment of typhoid fever. Background document: the diagnosis, prevention and treatment of typhoid fever. 2003. Available: www.int/entity/vaccine_research/documents/typhoi d_diagnosis.pdf via the Internet. Accessed: June 2014

20. Richens J, Parry C. Typhoid and paratyphoid fevers. In: Warrell DA, Cox TM, Firth JD, Benz EJ Jr, editors. Oxford Textbook of Medicine. Fourth 
edition Oxford: Oxford University Press. 2003: 503-507

21. Matsumoto $\mathrm{Y}$, Ikemoto $\mathrm{A}$, Wakai $\mathrm{Y}$, Ikeda $\mathrm{F}$, Tawara S. Mechanism of therapeutic effectiveness of cefixime against typhoid fever. Antimicrob Agents Chemother. 2001; 45:2450-2454.

22. Liu P, Muller M, Grant M, Obermann B, Derendorf H. Tissue penetration of Cefpodoxime and cefixime in healthy subjects. J Clin Pharmacol. 2005; 45(5):564-569.

23. Cammie FL, Miller SL. Salmonellosis. In: Kasper DL, Braunwald E, Fauci AS, Hauser SL, Longo DL, Jameson JL, editors. Harrison's Principles of Internal Medicine. Sixteenth edition, New York: McGraw-Hill. 2005: 897-900.
24. Pandit A, Arjyal A. Typhoid and paratyphoid fever. Lancet. 2005; 366:1603.

25. Kalra SP, Naithani N, Mehta SR, Swami AJ. Review article Current trend in the management of typhoid fever. MJAFI. 2003; 59:130-135.

26. Background document: The diagnosis, treatment and prevention of typhoid fever. World Health Organization. 2003:20.

27. Girgis NI, Butler T, Frenck RW, Sultan Y, Brown FM, Tribble D, Khakhria R. Azithromycin versus ciprofloxacin for treatment of uncomplicated typhoid fever in a randomized trial in Egypt that included patients with multidrug resistance. Antimicrobial agents and chemotherapy. 1999 Jun $1 ; 43(6): 1441-4$ 